\title{
Wnt pathway activation functionally reprograms human antigen-specific T cells
}

\author{
Yen-Ling Chiu', Bo-yi Sung ${ }^{2}$, Catherine Bessell ${ }^{3 *}$, Mathias Oelke ${ }^{4}$, Jonathan Schneck ${ }^{4}$ \\ From Society for Immunotherapy of Cancer 29th Annual Meeting \\ National Harbor, MD, USA. 6-9 November 2014
}

Polyfunctionality is a hallmark of protective immunity, yet the molecular mechanisms governing polyfunctional $\mathrm{T}$ cells are poorly understood. After TCR activation, naïve $\mathrm{CD} 8^{+} \mathrm{T}$ cells undergo proliferation and differentiation, which lead to effector functions and memory subset development. However only a portion of activated $\mathrm{T}$ cells develop into memory $\mathrm{CD}^{+} \mathrm{T}$ cells and with chronic stimulation become terminally differentiated and exhausted $\mathrm{CD} 8^{+} \mathrm{T}$ cells, as defined by CCR7 ${ }^{-} / \mathrm{CD} 45 \mathrm{RA}^{+}$, and functionally impair effective immune responses [1]. We therefore probed the ability to reverse terminally differentiated antigen-specific cells using pharmacological agents. Stimulating human memory $\mathrm{CD}^{+} \mathrm{T}$ cells with cognate TCR stimulation in the presence of Wnt agonist enhances polyfunctionality and stemness. Both M1-influenza ${ }^{+}$and $\mathrm{CMV}^{+} \mathrm{CD}^{+} \mathrm{T}$ cell responses were reprogrammed and revealed sustained effects from initial Wnt pathway activation in vitro. Future work with cancer antigens and reprogramming of differentiated $\mathrm{CD}^{+}$responses could lead to improved in vitro culture conditions for adoptive immunotherapy.
doi:10.1186/2051-1426-2-S3-P4

Cite this article as: Chiu et al:: Wnt pathway activation functionally reprograms human antigen-specific T cells. Journal for ImmunoTherapy of Cancer 2014 2(Suppl 3):P4.

\begin{abstract}
Authors' details
${ }^{1}$ Department of Medicine, Far-Eastern Memorial Hospital, New Taipei City, Taiwan, Taiwan. ${ }^{2}$ Department of Pathology Johns Hopkins University School of Medicine, Baltimore, Maryland, USA. ${ }^{3}$ Department of Medicine, and Institute for Cell Engineering, Johns Hopkins University School of Medicine, Baltimore, Maryland, USA. ${ }^{4}$ Johns Hopkins School of Medicine, Department of Pathology, Institute for Cell Engineering, Baltimore, Maryland, USA.

Published: 6 November 2014

Reference

1. Seder R, Darrah $P$, Roederer M: T-cell quality in memory and protection: implications for vaccine design. Nat Rev Immunol 2008, 8:247-258.
\end{abstract}

Submit your next manuscript to BioMed Central and take full advantage of:

- Convenient online submission

- Thorough peer review

- No space constraints or color figure charges

- Immediate publication on acceptance

- Inclusion in PubMed, CAS, Scopus and Google Scholar

- Research which is freely available for redistribution
() Biomed Central

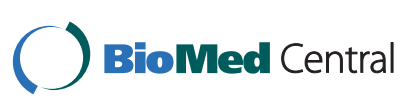

(c) 2014 Chiu et al.; licensee BioMed Central Ltd. This is an Open Access article distributed under the terms of the Creative Commons Attribution License (http://creativecommons.org/licenses/by/4.0), which permits unrestricted use, distribution, and reproduction in any medium, provided the original work is properly cited. The Creative Commons Public Domain Dedication waiver (http:// creativecommons.org/publicdomain/zero/1.0/) applies to the data made available in this article, unless otherwise stated. 